\section{Ideas for Financing African Higher Education}

\section{Damtew Teferra}

Damtew Teferra is a doctoral candidate in higher education administration in the School of Education, Boston College. He is currently coordinating a project funded by the Ford Foundation to produce a comprehensive sourcebook on African higher education. Address: School of Education, Boston College, Chestnut Hill, MA 02467, USA. E-mail: <teferra@bc.edu>.

$\mathrm{H}$ igher education is a costly business. It requires mobilizing a wide array of personnel at all levels of training as well as maintaining a vast and complex infrastructure. Even affluent nations, let alone the impoverished countries of Africa and the Third World, find it increasingly difficult to maintain adequate levels of financial support for their higher education institutions. While reports on the dismal state of most African institutions abound, this article outlines a number of potential ways of expanding the financial resource base of these institutions.

Promoting Private Institutions. Private institutions are slowly but steadily emerging in several African countries. Kenya and South Africa currently each have a dozen private institutions; according to a recent report, Benin has 27 private institutions. ${ }^{1}$ However, most of these institutions have small enrollment capacities.

A good number of African university students come from families in the growing middle and upper classes. This means that many students would be able to pay for their studies should alternative means of acquiring a higher education become available. Private institutions should be promoted so as to relieve governments of some of the burden of providing higher education for their citizens. Incentives by way of tax relief, land grants, and import exemptions should be put in place to attract investors. Favorable loan schemes and loan guarantees from bodies such as the World Bank should be seriously considered to support the establishment, operation, and maintenance of private higher education institutions.

Tuition and fees. Time and again efforts to reform a university's funding system have resulted in student unrest. Even selective attempts to impose fees on those who can afford them have been fiercely resisted. Notwithstanding the challenges, a strong case can be made in favor of charging tuition and fees by pointing out that poor taxpayers should not have to subsidize the education of the children of the affluent.

Local resources. Governments, private businesses, and organizations often employ overseas experts, ignoring exist- ing local expertise. A World Bank report estimates that around $\$ 4$ billion is spent in Africa per year on foreign technical assistance. ${ }^{2}$ These experts, however, commonly rely on local expertise and institutions.

African higher education institutions should seek to increase their share from such sources. The academic community should mobilize to market itself as a provider of better, cheaper, and more appropriate consultancy and technical services. Such productive links would benefit local scholars, strengthen the research and teaching environment of the institutions, and attract additional research funding.

Links with the private sector. The usefulness of collaboration and cooperation with private businesses has generally been accepted in many African universities. However, although various university-industry cooperative schemes exist, they have not been effectively exploited. To be successful, the links require the cooperation of government officials, university administrators, the business community, and scholars. Universities should actively engage the private sector's help in identifying the gaps in areas of expertise, human resources, and research. This approach would not only encourage businesses to employ graduates-and faculty-but would also promote further collaborative ventures.

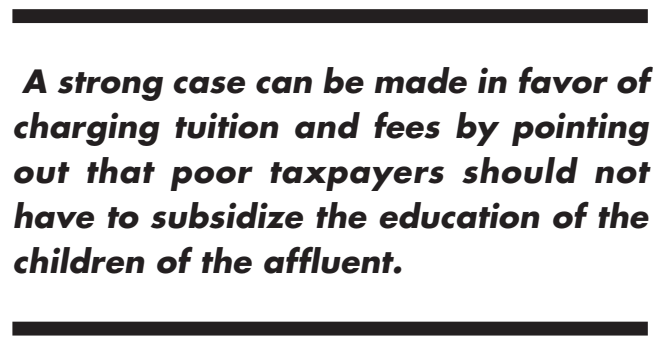

Alumni-recruiting initiatives. African scholars in the diaspora, particularly in the West, are an untapped resource with great potential not only for financial and material assistance, but also as promoters of African institutions and their alma maters. This effort could also be extended to nonalumni. African nations that have suffered from massive exodus of their experts should make a conscious effort to exploit the situation. In this, Africa should learn from India, China, and some other Asian and Latin American countries.

Resource sharing. Most African institutions of higher education lack effective resource-sharing mechanisms. This has often led to redundancy, "reinventing the wheel," and wastage of meager resources. As institutions strive to acquire more resources, they should also make a concerted 
effort to better manage the resources at their disposal. Establishing consortia between related institutions would be one effective strategy.

Income-generating programs. Institutions can generate revenues by hosting short courses, seminars, summer programs, and conferences. Businesses, governments, and nongovernmental organizations are generally supportive of training schemes in highly regarded institutions. Universities should capitalize on their reputations.

\section{African scholars in the diaspora, par- ticularly in the West, are an untapped resource with great potential not only for financial and material assistance, but also as promoters of African insti- tutions and their alma maters.}

Financial management systems. The financial systems in many African universities are generally quite poor. Numerous reports on African institutions criticize their management systems as overly bureaucratic, inefficient, and insensitive. Financial systems should be compatible with the idiosyncrasies and the needs of the communities they serve.

Private companies and $R \triangleleft D$. Research and development can be promoted by involving local institutions with private and multinational companies-for example, by instituting tax exemptions. This is a potential way of supporting higher education institutions engaged in the fields of agriculture, pharmaceutics, industry, and commerce. Africa should seriously look to Asia (e.g., South Korea) for models of countries that became industrial giants through government support for science and technology and the enactment of laws to encourage private industries.

Distance learning. Many countries in Africa are currently engaged in promoting tertiary distance education. According to the Association for the Development of Education in Africa, tertiary distance learning holds the potential to expand access to quality higher education at affordable cost and should be an integral part of any educational system. ${ }^{3}$ The African virtual university, established through the support of the World Bank is one such example. This has a potential to increase access and programs while generating some revenue.

Grant-writing expertise. Many African scholars have little experience in preparing major funding proposals for ex- ternal agencies. Although funding has been slightly curtailed in recent years, many missed opportunities are simply the result of inexperience with the process and requirements of grant and donor funding. ${ }^{4}$ Notwithstanding the consequences of following donor agendas, university research offices should play an active role in training their faculty, referring them to prospective donors and the areas they emphasize.

Government support. Social and economic development in an increasingly information- and technology-driven world can only be attained with a highly trained workforce. Recent developments in science and technology dictate that the cost of higher education be considered an investment that will determine the destiny of Africa in the high-tech world of the next century. Therefore, African higher education institutions should lobby their governments, other powerful and influential constituencies, and the public by highlighting and reaffirming their raison d'être.

\section{Conclusion}

Expanding the financial resource base for African higher education institutions has to be actively, selectively, and carefully accomplished. To offer one caveat: any "solutions" may harbor their own intrinsic "defects." Local, national, regional, and international realities need to be taken into account prior to the undertaking of such initiatives. Academic institutions must be prudent in balancing their academic duties with entrepreneurship. There is little doubt that taking up these initiatives and actively engaging all the stakeholders require a conscious, qualified, and concerned university management.

\section{Academic institutions must be prudent in balancing their academic duties with entrepreneurship.}

\section{Notes}

1. Corbin M. Guedegbe, "Higher Education Reform in Benin in a Context of Growing Privatization," International Higher Education no. 16 (summer 1999).

2. World Bank, The African Capacity Building Initiative: Toward Improved Policy Analysis and Development Management in SubSabaran Africa (Washington, D.C.: World Bank, 1991).

3. Tertiary Distance Learning in Africa, Association for the Development of Education in Africa (ADEA), Working Group on Higher Education Report, October 20-22, 1997(Saint-Louis, Senegal: ADEA, 1997).

4. F. M. Hayward, "The Changing African Landscape: Implications for Higher Education," Educational Record (fall 1991): $34-39$. 